Stellenbosch Theological Journal 2017, Vol 3, No 1, 185-204

DOI: http://dx.doi.org/10.17570/stj.2017.v3n1.a09

Online ISSN 2413-9467 | Print ISSN 2413-9459

2017 @ Pieter de Waal Neethling Trust

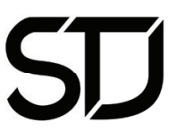

\title{
Discipleship misconceptions: A social scientific reading of James and John's request for seats of honour (Mark 10:35-42)
}

\author{
Kgatle, Mookgo Solomon \\ University of Pretoria \\ kgatles@yahoo.com
}

\begin{abstract}
This article is a social scientific reading of James and John's request for seats of honour in Mark 10:35-42. It argues that when James and John made such a request they misunderstood the meaning of discipleship. The argument is established by looking at the literature review on Mark 10:35-42. Discipleship as presented in Mark is described to understand the type of discipleship demanded by Jesus. The discipleship misconceptions are also outlined in detail. The purpose here is to demonstrate that the disciples of Jesus, James and John, in Mark 10:35-42 misunderstood the meaning of discipleship as presented in Mark. The article makes a contribution to the ongoing research on New Testament scholarship by studying Mark 10:35-42 through a social scientific criticism.
\end{abstract}

Key words

Kinship; self-interest; position; competition; lordship and authority

\section{Introductory remark}

There are four different approaches to New Testament exegesis that one can use to approach Mark 10:35-42. The approaches are diachronic, synchronic, reader-response and social-scientific. The diachronic (e.g. form, source, etc) focus on the history of the text. Synchronic (e.g. discourse analysis, rhetorical, text, narratology) focus on the text itself (Catchpole 1997:168). In reader-response criticism ${ }^{1}$, the reader is inscribed or encoded in the text,

1 See the five characteristics of reader-response criticism (Porter 1990:279); a common image used to explain the reader-response approach is to suggest that the text functions 
is a property of the text, and is part of the text's meaning. The function of the reader is to interpret the signals transmitted to the text. The reader interacts with the text; meaning will thus be a product of the dynamic text interaction (Resseguie 1984:307).

This article uses the social-scientific criticism² because it sees Mark 10:3542 as a product of a specific social system. It aims to avoid anachronism and ethnocentrism by focusing on the social system that produced the text (Horrel 1999:21). This will be done by looking at the literature review of Mark 10:35-42. Discipleship as presented in mark is described to understand the type of discipleship demanded by Jesus. The discipleship misconceptions are also outlined in detail. The purpose here is to demonstrate that the disciples of Jesus, James and John in Mark 10:35-42 misunderstood the meaning of discipleship as presented in Mark.

\section{The literature review on Mark 10:35-42}

Blaney, Hanson and Harvey (1955:137) points out that the text is about the two sons of Zebedee ${ }^{3}$ who came to request for positions of pre-eminence in Christ's glory. Evidently they were either wanting places of honour at the messianic banquet, or places of honour and authority in a political messianic kingdom which they thought was about to appear.

as mirror instead of window (Cahill 1996:89); it is the reader who has to fill the gaps in the text with meaning, as well as to iron out the repetitions, doublets and inconsistencies (Du Rand 2005:52); reader-response critics are typically in the capacity for any text to mean different things to different people (Powell 2009:54).

2 No text can responsibly be interpreted if the social system that produced the text is not taken seriously (van Eck 2013a:238). Social scientific criticism does not only studies (1) the social aspects of the form and content of texts but also the conditioning factors and intended consequences of the communication process, (2) the correlation of the text's linguistic, literary, theological (ideological), and social dimensions and (3) the manner in which this textual communication was both a reflection of and response to a specific social and cultural context, that is, how it was designed to serve as an effective vehicle of social interaction and an instrument of social as well as literary and theological consequence (Elliott 1993:7).

3 Zebedee was a Galilean fisherman, father of the apostles James and John (Mk 1:19-20; $3: 17 ; 10: 35)$. He was the husband of Salome and in all probability lived in the vicinity of Bethsaida (Mk 15:40). One would judge that he had been a man of means and influence because of Mark's reference to his hired servants (Mk 1:20) 
A study on Mark 10:35-42 is a fitting climax to the theme of discipleship (Johnson 1972:178). This study is not only about discipleship but the disciples' misunderstanding of the teachings presented by Jesus. Anderson (1976:254) states that Mark's dominant theme is the disciples' lack of understanding in the face of the truth. They misunderstand that God's way of suffering and sacrifice for Jesus is identical with God's way for His disciples. Sanner (1979:362) divides the text into two major themes, Selfish seeking (Mark 10:35-40) and Selfless service (Mark 10:41-45).

Despite all what Jesus taught them, despite their intimate association with Him, despite everything they had seen Him do, the disciples could not understand Jesus as a suffering Son of Man (Achtemeier 1978:350). The disciples have two specific kinds of misunderstanding: the necessity of Jesus' sufferings and their own position in the community (Tyson 1961:262). They do not only misunderstand the message of suffering, but also reject Jesus' suffering, Son of Man Christology and call for suffering discipleship (Longstaff 1980:34).

Above the failure and the misunderstanding of the disciples according to Williamson (1983:190), this passage affirms that Jesus' life was one of service and that His death was for others. His life and death were peaceful, for the supreme service of Jesus Christ was the voluntary giving of His life as a ransom for many. The request for places of honour according to Gundry and Thomas (1988:165) displayed a continuing feeling among the disciples that Jesus was going to Jerusalem to restore the glory of the fallen throne and kingdom of David. This was a normal, though selfish, reaction to Jesus' recent words about the twelve's occupancy of twelve thrones in that kingdom. Not only had James and John missed the point with regard to humility, they had also failed to grasp the necessity for delay of the Messiah's coming passion.

Although the disciples do not understand Jesus the application of this teaching to the life of Mark's own community would have been clear. There may well have been church leaders there whose attitude was similar to that of James and John, seeing discipleship in terms of status and privilege (Hooker 1991:246). For them, the teaching that true greatness is seen in service was certainly necessary. At the same time, the threat of persecution was a very real one. The warning that being Jesus' disciple was 
likely to mean sharing His suffering may have been all too relevant to their situation. A public address to James and John and a public address to the ten, the attitude that Jesus demands of His disciples are based on imitating His own life of service and acceptance of death.

Jesus' teaching in this passage according to English (1992:182) shows discipleship as a self-denying, self-risking part of lowly service for the redemption of the world. In contrast much of Christian life is about gaining a secure position in society, inviting others to join us where we are, doing little to change the structures of our political and social life. Seeley (1993:234) combines two ideas in Mark 10:41-45, lordship and service. The two stand in sharp contrast to one another. Indeed, it is precisely the tension between them that gives the passage much of its force. Unlike those who are regarded as ruling over nations, a disciple of Jesus should become a servant if he wants to be first.

Furthermore, Jesus teaches His disciples that the places of honour are not His to appoint. Evans (2000:125) indicates that Jesus can tell them what is expected of the disciples. They cannot be like the "great one" of the world, who likes to rule over people. Instead, the disciples are to seek opportunities of service. Jesus Christ is the epitome of this service. As "Son of man" He does not desire to be served instead "seeks to give His life as a ransom for many". Geisler (2007:73) is adamant that Jesus in Mark 10:3545 instructs His disciples in humility and in service. Hutchison (2009:54) agrees that in Mark 10:42-45 Jesus challenged His disciples to a radical and paradoxical form of discipleship and showed that He Himself would provide the ultimate example through His suffering and death.

James and John made a request for positions with Jesus, asking if they can be guaranteed seats at His right and left in glory as a demonstration of failure of discipleship. Despite their failings, Jesus keeps them as His disciples. The point, for Mark, seems to be that discipleship is a relationship established by the call of Christ and defined by His own faithfulness, not by any merit that can be attributed to the disciples themselves (Powell 2009:142). Mark 10:35-42 is about two reprimands by Jesus to His disciples; the reprimand Jesus gave to two of His disciples for their ambitious request and the reprimand $\mathrm{He}$ gave the rest of the disciples for their uneasiness (Henry 2010:1594). 


\section{Discipleship as presented in Mark}

In Mark the life of the disciple is presented as being essentially continuous with that of Jesus (Waybright 1985:287). A disciple is one who is able to willingly accept the dislocations and disorientations which come with following the Son of Man (Barton 1994:150). Discipleship means to follow the way of being with others that may lead to suffering and death. Suffering is not an end in itself, but the consequence of a life-praxis of solidarity with the outcasts of society (Medley 1994:14). Discipleship for Mark is not construed as assent to a series of faith propositions or the full acquisition and understanding of divine mysteries. It is predicated on becoming connected with Jesus by following Him after His call and acting like Him because $\mathrm{He}$ is the manifestation of the kingdom of God on earth (AhearneKroll 2010:734). Becoming a disciple of Jesus meant taking up your cross and following Him into non-violent warfare against the spiritual powers of evil (Boomershine 2011:411).

Discipleship is not only about hearing the words of Jesus on suffering, but also to act upon the words so that others may follow (Donahue 1983:19). Mark has a unique description of the disciples; rather than idealise the first followers of Jesus, He seems to highlight their weakness and failure. They often appear confused and baffled; they misunderstand Jesus and recoil before the message of the cross (Senior 1984:36). The reason for the confusion of the disciples is that for the Markan Jesus the kingdom is a new inclusive household. This new household is opposed by the temple. In Galilee it seems that the new household and the disciples succeed in replacing the kingdom but not in Jerusalem. God's kingdom, which was announced as being near, has drifted from the horizon (van Eck 2011:85).

The conflict between Jesus and the disciples and that between Jesus and the authorities interweave, interpret and illumine each other. The disciples like the religious leaders, fail to grasp the essential nature of God's boundaryshattering reign. This nature expresses itself in a concept of messianic authority oriented not to power over others, but power exercised to spread holiness and life to a world locked in Satan's grasp. Both the disciples and the authorities stand to lose much in such a kingdom; they both fail to grasp the paradoxical truth driven home time and again by the Markan Jesus through his teaching, healing and suffering. The truth is that only by losing one's life to the powers of the world which stand opposed to 
God can one save it (see Hanson 1998:155). It was truth to be understood only through the paradox of a different value system. Hence Jesus' closest followers found the message of suffering, servant-hood and sacrifice difficult to accept (Hutchison 2009:57).

The disciples of Jesus cannot understand His message of suffering because discipleship is more costly than imagined and beyond the expectations of Jesus' disciples (Nightingale 2012:116). It involves cross-bearing, suffering, preference for the lowly and losing one's life. The disciples resisted and rejected; confused and fearful, they lacked understanding and failed to the utmost degree. They are drawn to Jesus, but do not understand what following the suffering Son of Man means. Although Jesus speaks about the suffering, rejection, death, and resurrection of the Son of Man the disciples do not understand these; instead they ask for special places of honour (Nicklas 2012:362).

\section{Social scientific reading of Mark 10:35-42}

\subsection{Background}

The community of Mark ${ }^{4}$, understood the message of discipleship (Hanson \& Oakman 1998:133). The earliest witnesses to Mark's gospel indicate that the first listeners to that gospel stood especially in 'need' of hearing precisely the message of Jesus about discipleship (Reardon 1992:108). Jesus' words about discipleship would fit the societal norms of Jewish Christians in Palestine because of their social cultural context. The community of Mark understood the message of the cross because they are suffering like Jesus did (Hutchison 2009:55).

However, according to the literature review discussed above, the disciples of Jesus do not grasp this message. The request made by James and John in Mark 10:35-45 raises five misconceptions of discipleship.

4 The community of Mark refers to the Jewish Christians in Palestine. This is because the author of the gospel takes it for granted that his readers accept the scriptures of Israel as the Word of God (you have let go of the commands of God and are holding on to the traditions of men; Mk 7:8; NIV). Again they understand what it means to give life as a ransom (sacrifice) for others - a reference to the system of sacrifice in the Old Testament ('For even the Son of Man did not come to be served, but to serve, and give His life as a ransom for many; Mk 10:45; NIV) It can therefore be concluded that Mark's first readers most probably were from Jewish descent (see van Eck 2013b:35). 
The first misconception is in view of the familial relationship that James and John, the sons of Zebedee had with Jesus. It was this close relationship that encouraged them to come to Jesus. 'James and John, sons of Zebedee, came up to Him, saying, Master; we desire that you should do for us whatsoever we shall ask' (Mk 10:35). They had the courage to approach Jesus because they knew they were closely related to him. This is called kinship misconception.

Secondly, they asked Jesus to grant them their own desire. This can be seen as ambitious, vanity and self-centredness. The two disciples perceived discipleship as pursuing self-interest. It is called ambition misconception.

Thirdly, in Mark 10:36-37, 'He said unto them, what would you that I should do for you?' They said unto him, 'grant unto us that we may sit, one on thy right hand, and the other on the left hand, in your glory'. They thought that discipleship was the place that a person sits in, or a position that one occupies. This is called honour misconception.

Fourthly, the other ten disciples responded with indignation in Mark 10:41, 'and when the ten heard it, they began to be extremely displeased with James and John'. They wanted to compete with James and John. This would suggest that they equally wanted to sit on the left and right. Therefore the fourth misconception is competition. Finally, in Mark 10:42, 'Jesus called them to Him, and says unto them, you know that they which are accounted to rule over the Gentiles exercise lordship over them; and their great ones exercise authority upon them'. Jesus knew that their idea of discipleship is about lordship and authority over the followers. Therefore the final misconception is lordship and authority.

\subsection{Discipleship misconceptions in Mark 10:35-42}

\subsubsection{Kinship}

'James and John ${ }^{5}$, the sons of Zebedee, came up to Him, saying, Master; we desire that you should do for us whatever we shall ask' (Mk 10:35).

5 James and John, the sons of Zebedee, were Galilean fishermen and two of the twelve disciples of Jesus (Mk 1:19-20). James, John and Simon (Peter) comprise a trio that attained a place of prominence among the disciples of Jesus in Mark. They are often found at the centre of important events, such as the raising of Jarius's daughter (Mk 5:37), the transfiguration ( $\mathrm{Mk} 9: 2$ ), and Jesus' agony in the garden of Gethsemane (Mk $14: 3)$. 
Kinship ${ }^{6}$ and politics were the most fundamental social structures of the first century Mediterranean world. All other social institutions, such as economics, education and religion, were embedded in them (Malina 1986:84). Kinship is a dominant category of social organisation in traditional Mediterranean societies. The family in a traditional Mediterranean society can be understood as a diachronic and synchronic association of persons related by blood, marriage and other social conventions, organised for the dual purpose of the enhancement of its social status and the legitimate transfer of property (Osiek \& Balch 1997:41).

Jesus' disciples were a part of this value system. Life was viewed and interpreted in the context of a familial relationship. James and John thought that they can easily ascend to higher levels because they are very close to Jesus. They took an advantage of the close relationship that they had with Jesus and the influence of their mother. This familial relationship coupled with the relationship in ministry gave them confidence to make request for places of honour.

Kinship is not only about familial relationship but also about race relations. People who are not related by blood are bound together by common tribal or racial blood (Robinson 1940:330). Fictive kinship relationships for example are fictional and not blood relationships. Another term sometimes used is "surrogate family," suggesting that the relationships are an alternative family to blood relations. "Metaphorical kinship" refers to a more real family of God. Kinship goes beyond blood relationship to include other mutual relationships (Rhoads 2004:284).

James and John did not only rely on the familial relationship but they were also part of Jesus' ministerial group. They were part of the team that Jesus took to a higher level of His ministry. This group is not necessarily related through blood but through sharing common beliefs and principles. The fact that they were a part of Jesus' inner circle is what made them desire to be given these positions.

6 Kinship is the network of social relationships that form a significant part of the lives of most humans in most societies. Kinship refers to blood relationships. It refers to people who have similar characteristics and origin (Bill 2001:532). 
Discipleship is not limited to kinship. Jesus is suggesting a way of life which differs from what would have been perfectly accepted in the context in which he lived. Jesus reinterpreted the concept of family relationship. Kinship through blood was enlarged, if necessary, superseded to include all those who chose to do the will of God. People actually did follow Jesus as a group of brothers and sisters. They ate together, talked together and visited in each other's houses regardless of their colour, age or gender (Finger 1994:28). The children of God became a fictive kinship group, that is, a collection of people who are not genealogically related but who nevertheless consider one another as family, having belonging and mutual commitment (Desilva 2004:76).

\subsubsection{Ambition}

'James and John, the sons of Zebedee, came up to Him, saying, Master; we desire $\left(\theta \dot{\varepsilon} \lambda \mathrm{o} \mu \varepsilon v^{7}\right)$ that you should do for us whatever we shall ask' (Mk 10:35).

James and John were very ambitious in their request. Ambition in this context refers to an instinct of nature, a desire to rise; and like all other instincts, capable of good and evil (Burn 1974:385). An ambition can be negative or positive. It depends on the motive of an ambitious person. If for example a person has a positive motive then that ambition is positive. The opposite is also true; anyone with a wrong motive is more likely to have a negative ambition. Motive in this context is the reason behind the request that James and John made to Jesus.

James and John gave signs of a selfish, self-centred, egocentric desire or negative ambition. They exposed their weakness in discipleship. It reveals that James and John did not know the true cost of a high place in the kingdom of God, otherwise they would not have dared to make such a request in spite of their brave words (Carson, Motyer \& Wenham 1994:966). In addition, the request by James and John showed a lack of spirituality, short memory and unabashed selfishness (Sanner 1979:360).

It was not wrong for James and John to make a request to be part of Jesus' glorious kingdom. The problem is that they make such a request in a selfish

$7 \Theta \varepsilon \dot{\lambda}{ }_{0} \mu \varepsilon v$ it means to I will, wish, desire, am willing, intend, design. 
manner. It is not about the kingdom of heaven but about the two positions to be occupied by two people only. They want Jesus to do what they want. They are asking for a 'blank cheque', they do not care about what Jesus wants and desires for His disciples. They misunderstand Jesus' message about the glorious kingdom. It is not necessarily about seats or position, but service (Mk 10:45).

\subsubsection{Honour}

'He said unto them, what would you that I should do for you? They said unto him, Grant unto us that we may sit, one on thy right hand $(\delta \varepsilon \xi i \tilde{\omega} v) 8$,

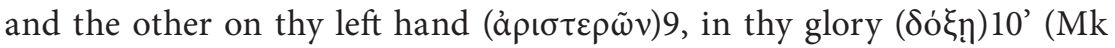
10:36-37).

James and John desired to sit one on the left and the other on the right. The left and right hand in glory speak about positions of honour ${ }^{11}$. James and John believed they had prior knowledge that Jesus would not only die on the cross, but also resurrect and reign again as the king and restore the kingdom of God. This, after all, was Jesus' statement about His death, and this caused the sons of Zebedee to ask for positions of power at Jesus' right and left hand (Senior 1984:31). In requesting to sit on the left and the right hand side, James and John were evidently either wanting places of honour at the messianic banquet, or places of honour and authority in a political messianic kingdom which they thought was about to appear (Earle, Blaney \& Hanson 1955:137). James and John, having witnessed the transfiguration, realised that Jesus will come in glory; yet they cannot rise above the concept of earthly messiah-ship. They asked to be seated at His

8 ' $\delta \varepsilon \xi_{1} \tilde{\omega} v$ ' means to sit or stand at the right hand of any one, as a mark of the highest honor and dignity which he can bestow (see Mounce \& Mounce 2008:1038)

9 ả $\rho ๘ \tau \varepsilon \rho \tilde{\omega} v$ is equally a glorious position (see Mounce \& Mounce 2008:1022).

$10 \delta$ ó $\xi \eta$ it refers to honour, renown; glory, an especially divine quality, the unspoken manifestation of God, splendour.

11 Honour is the socially approved and expected attitudes and behaviour in the areas where power, sexual status and religion intersect. It is the public claim to worth and status along with the social acknowledgement of such worth status and reputation" (Elliott 1993:130). Each male had a sense of worth as a person, and this status had to be recognised by others. Today the life of Westerners (including developing nations under Western influence) centres on economics and all that goes with it, such as labour, production, consumption and possession. These do not only motivate many people's behaviour, but claims most of their time and energy. It is basically what people live for (Mahlangu 2001:89). 
right and His left as the two principal members of His 'cabinet' (Johnson 1971:179).

The two places described here are those of honour everywhere, not only in the east or in ancient times, but at any public dinner no less than in royal courts (Alexander 1960:290).

These two places either refer to the present or future moment. The present moment in the sense that Jesus is about to sit and dine with His disciples at the last supper table. The future moment relates to the events of the last days. Jesus will reign and rule as king. The latter is more probable, given the fact that prior to the request Jesus had already made such a promise to the disciples. The request may be for the places of honour at the messianic banquet or for the position of eminence and authority at the Parousia, when Jesus is enthroned as the eschatological judge (William 1974:379).

James and John knew that positions in the messianic kingdom would be influential. They knew that the right hand side is the side of authority and dominion. The right hand is 'your right side' or 'your strong arm'. Equally so the left hand side is not an ordinary seat, but a seat of command (Bratcher \& Nida 1961:332). It was not mere desire to be near Jesus at the moment of triumph that moved them to this request. It was ambition not loyalty that motivated such a request. For John, at least, it must have seemed a natural extension of his position as the disciple of love (Cole 1961:169). James and John first believed that Jesus was about to establish a messianic kingdom and therefore the sons of thunder asked for the highest positions possible (Williamson 1983:192).

The request to sit at Jesus' right and left is an inevitable reminder of the account of the death of Jesus, when two robbers are crucified on His right and left. This is probably a deliberate irony, even though the promise that the seats of glory belong to those for whom they have been prepared refers to places of honour in the kingdom of God (Hooker 1991:247).

Another matter that needs attention is the fact that James and John were not only asking for seats, but seats in His 'glory'. Glory in this context refers to power, majesty, might, that which belong to a king (Bratcher 1981:139). In addition the request was precipitated perhaps by the excitement of coming closer to Jerusalem, the 'royal city', assuming that Jesus as 'king' will have a position of honour and influence. To speak of sitting (rather than reclining, 
as at a banquet) on the right (or left) of someone implies a royal throne with places of the highest honour on either side. There are of course only two such places, leaving no room for Peter. The fact that the word glory is used, confirms that they envisaged Jesus as 'king' (France 2002:17).

The first statement of John and James, namely 'that we may sit', it is hard to know whether James and John are evoking the image of the messianic banquet or that of the heavenly throne. Their second statement, 'one at your right hand and one at your left', is ironic in the sense that Jesus is crucified with two bandits one on the right and one at the left. Their last statement, 'in your glory', may refer to the glorious Parousia that James and John know but their willingness to ignore the content of Jesus' very detailed passion predictions reveals the depth of their misunderstanding of Him (Donahue \& Harrington 2002:311). Traditionally, the seats to the right and left of the monarch or king were, in an oriental court, seats of honour, seats that symbolised special dignity. They were not ordinary seats, but seats of great importance. These seats belonged to a selected few or the royal house. Equally so, glory is a metaphor for 'kingly power' (Thurston 2002:116).

\subsubsection{Competition}

'And when the ten heard it, they began to be much displeased (å $\gamma a v a \kappa \tau \varepsilon \tilde{v}))^{12}$ with James and John' (Mk 10:41).

The ten means the other ten disciples other than James and John as they were twelve disciples in total. They were displeased, or grieved and indignant on the account of the request that James and John had made (Alexander 1960:292). There are two possibilities for the indignation of the other ten disciples: they either wanted to defend Jesus' teaching on discipleship and greatness in the kingdom (Mk 9: 30-50) or they wanted to contest James and John for similar positions (Thurston 2002:117).

They were not angry because James and John missed the point but because James and John were quicker than them in making the request. When the ten became aware of this selfish request they became indignant because they, too, wished preferment (Earle, Blarney \& Hanson 1955:138). The other ten overheard this blatant grab for power and became indignant, suggesting

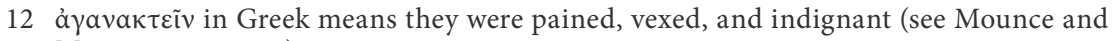
Mounce 2008:1000) 
that they were harbouring the same vision. They possibly wanted the only two limited seats in the messianic kingdom and were angry that they are about to be occupied (Elmer 2006:23).

The ten, in turn, portrayed their spiritual shallowness by being indignant of the spiritual shallowness of the two who had skilfully stolen a march on them. A man's character is shown by the things that provoke his strongest reactions; and so Jesus justly rebuked all of them at once by showing them their common ignorance of the very nature of discipleship (Cole 1961:170). They shared in this blatant failure when they became indignant at the nimble manoeuvre of James and John. The ten reacted to the situation instead of responding to it. They perceived discipleship as jostling and wrestling for limited positions instead of perceiving it as an opportunity to serve others (Senior 1984:31).

The other ten disciples were indignant because they were jealous of their own dignity and fearful lest the two brothers should secure some advantage over them. Their insensitivity to the seriousness of the moment links them with James and John, and suggests the cruel loneliness with which Jesus faced the journey to Jerusalem (William 1974:382). It also indicates the degree to which selfish ambition and rivalry were the raw material from which Jesus had to fashion discipleship.

If the two sons of Zebedee appeared in a poor light, the remaining ten disciples were no better, for when they heard of it became angry at James and John (Sanner 1979:361). The ten had the opportunity to correct James and John and receive praise from Jesus. They missed such an opportunity and as a result they are also the subject of Jesus' reprimand. The ten had an opportunity to be models and champions of greatness and service. The other ten disciples might have come out of this incident as models, but when they learned what had happened they showed their anger at James and John, perhaps at being upstaged by them (English 1992:182).

For a moment one may think that the ten disciples were angry for good reason, but they were not. Williamson (1983:192) remarks that when the other ten heard of the request, they began to be indignant with James and John. Their anger may have been perceived as moral indignation at James and John's ambition, but the picture of the disciples throughout Mark leads the reader here to suspect that the other ten were angry because they 
wanted those places for themselves. Hooker (1991:247) agrees that the ten were indignant with James and John not because their own attitudes were different, but because they also wanted to make the same request. Hence, Jesus summoned them and addressed the whole group.

The ten other disciples behaved like James and John when they were angry with them because of their request. There is no doubt they had wanted these places for themselves. As a result Jesus explained to them once more the totally different pattern of God's kingdom where greatness is humble service (Carson et al. 1994:967). The annoyance of the ten was not over the ambition of the two brothers. It was over the fact that James and John have made their request first and tried to gain an unfair advantage over their colleagues in the competition for the highest places. On this issue they were all equally at fault (France 2002:18).

Perhaps it was because the other ten were not included in the inquiry. It is more likely that the other disciples were irritated because James and John were using their familial ties with Jesus. They used the influence of their mother to 'get the edge' on acquiring positions in the kingdom (Hutchison 2009:59). The other ten disciples were angry at the two for seeking precedence, because each of them hoped to have it for himself. Here we see the disciples revealing their own ambition, in their indignation at the ambition of James and John. Jesus used this occasion to warn them against negative ambition (Henry 2010:1595). The other disciples were 'indignant' with James and John for their request of special honour, perhaps because they secretly hoped for it themselves (Mk 10:41). The dissension among the twelve becomes the pretext for one of Jesus' most important lessons and self-revelation (Burge \& Hill 2012:1036).

\subsubsection{Lordship and authority}

'But Jesus called them to Him, and says unto them, you know that they which are accounted to rule over the Gentiles exercise lordship

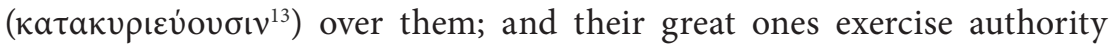

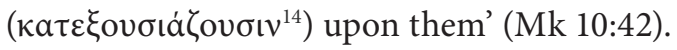

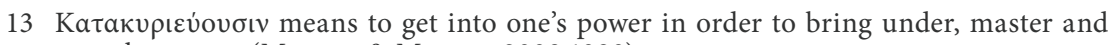
over the person (Mounce \& Mounce 2008:1090)

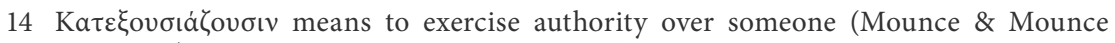
2008:1094) 
The word Gentiles $(\dot{\varepsilon} \theta \nu \tilde{\omega} v)^{15}$ used in Mark 10:42 refers to political authorities, who, in their exercise of authority, embody the prevailing norms for measuring greatness. These norms are as prevalent now as they were then. The phrase 'It shall not be so among you' suggests the goal of discipleship is to transform the entire culture (Williamson 1983:195). The expression that the same leaders rule or lord over others needs further explanation in order to understand what Jesus is saying to His disciples. 'Accounted to rule' refers to the unsubstantial nature of all human principalities and powers or those who are recognised as chiefs and generally known to be so (Alexander 1960:293).

Bratcher and Nida (1961:332) elucidate all the concepts in this text: To

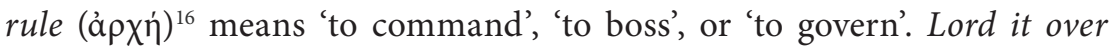

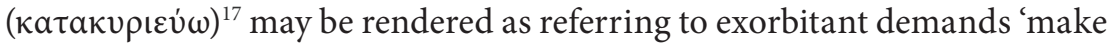
them run back and forth' in the sense of constantly running errands or self-exaltation. Great ( $\mu \dot{\varepsilon} \gamma \alpha \varsigma)^{18}$ is usually interpreted in terms of physical strength, with metaphorical extensions such as 'strong', 'mighty', 'powerful' or 'authority' or position to command 'with authority'. Exercise authority

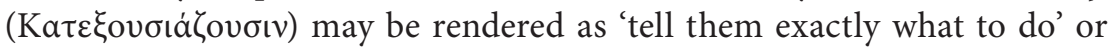
'constantly boss them'.

These leaders are those who are recognised as ruling the Gentiles, possibly 'reputed as ruling' or 'seem to rule'; for although people recognise their rule, they are not the ultimate rulers. Such leaders lord over them, and this was expected in the ancient world. It is still true in political and economic life that the exercise of power impresses people, but Jesus was an exception to the rule (Johnson 1971:180). When Jesus says, 'are considered', it does not mean that Jesus is denying that such leaders are, in fact, rulers. Perhaps the best way to represent the idea is to say, 'who assume the right to rule' or 'who claim to be rulers'. Rulers of heathens are leaders who govern people who do not believe in God, and as a result they rule over them (Bratcher

$15 \dot{\varepsilon} \theta v \tilde{\omega} v$ means nations but usually refer to the non-Israelites (Mounce \& Mounce 2008:880)

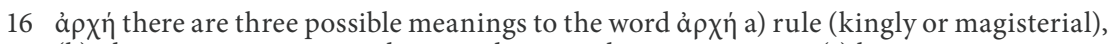
(b) plur: in a quasi-personal sense, almost: rulers, magistrates, (c) beginning

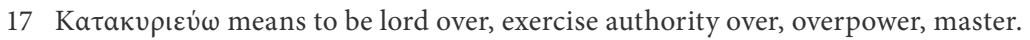

18 Mغ́үac large, great, in the widest sense. 
1981:139). The terms 'rule' and 'Lord it over' help to characterise this experience as one of being subject to unlimited and overwhelming imperial power (Donahue \& Harrington 2002:312).

In seeking to impress the truth of Mark 9:35 on the twelve, Jesus contrasted the conduct of Gentile rulers with the submission to service and sacrifice which is appropriate for discipleship. It is probable that His most direct contact with the expression of power and authority of the petty rulers of Palestine and Syria and the great lords of Rome was through the coins which circulated in Palestine (William 1974:382). The text further illustrates a difference between Jesus-followers and unbelievers. The Kingdom concept of greatness is opposed to that of the secular world; strictly speaking the contrast is not between two ways of exercising authority, the good way (that of Christians) and a bad way (that of secular rulers), but between good or bad authority and service (Best 1981:126).

The point is that the text combines two ideas, namely: ruler-ship and service which stand in sharp contrast to one another. Indeed, it is precisely the tension between them that gives the passage much of its force. Unlike those who are regarded as ruling over nations, disciples of Jesus should become servants if they want to be great and a slave of all if they want to be first (Seeley 1993:234).

Jesus' response is a clear and accurate picture of the manners and behaviour of earthly lords and rulers, practised by the Greco-Roman world (Thurston 2002:117). Jesus takes up the idea of royal privilege from the brothers' request and universalises it to refer to the Gentiles. It is not so much, however, that Jesus wishes to acquit Jewish leaders of the sort of attitude towards authority which Gentiles display, but rather if you wanted to see absolute power in the world of the first century it was necessary to look outside politically; where Israel was subjected to those who held real power (France 2002:18).

There are two kinds of authority; the Gentile authority and the authority of the kingdom of God. One is authority over and the other is authority under (Schroeder 2006:298). The disciples must shun Gentile authority and embrace the authority of the kingdom of God. When they follow Gentile authority they become like those who rule and lord it over others. Jesus censures all of the disciples with His more severe reprimands (Elmer 
2006:23). Rulers like Caesar, Herod the Great, Herod Agrippa and other Roman magistrates were regarded as the most powerful human figures of their day. Jesus said that Gentile rulers, 'lord it over' others (Hutchison 2009:64).

Jesus knew that political rulers wielded immense power. Their subjects had to submit to their authority. As leaders, they could throw their weight around. At the same time, they craved popularity. They wanted to play the role of benefactor, so they liberally dispensed privileges (Hian 2010:16). Dominion was generally abused in the world of Jesus. The concern of the rulers was what they can get from their subjects to support their own pride and grandeur, not what they could do for them. That dominion therefore should not be admitted into the followers of the Jesus movement. The leaders must be like shepherds taking care of the sheep. Followers should not be like horses under the command of the driver (Henry 2010:1595).

Domineering over other people was the culture and custom of the day. It was a system that took pride in exercising authority and lording over other people. Jesus exposes that culture and its way of doing things. He indicates that even if it is common to abuse power, it is not the only way of leading people. Jesus points to the surrounding culture and its way of leading. The surrounding culture dominates and in most cases oppresses those under their rule (Sweet 2012:33). In fact, it celebrated that domination-that hierarchy. It again esteemed the rights and privileges that come from being on top. Jesus calls the disciples instead to follow the model of the house servant and the bond slave that is to give up rights and privileges in order to serve the interest of another.

\section{Conclusion}

The literature review on the context of Mark 10:35-42 showed that it is about discipleship misconceptions. The article used social scientific criticism to expand on these discipleship misconceptions. The first misconception is kinship in view of the familial relationship between Jesus and the sons of Zebedee, James and John. The second one is ambition because the disciples asked Jesus to grant them their own desire (Mk 10:35). The third misconception is called honour as James and John thought that discipleship was about the place that a person sits in or a position that one 
occupies (Mk 10:36-37). The fourth one is competition because the other ten disciples responded with indignation suggesting that they equally wanted to sit on the left and right (Mk 10:41). Finally, Jesus knew that their idea of discipleship is about lordship and authority over others (Mk 10:42).

\section{Bibliography}

Alexander, JA 1961. The gospel according to Mark. London: Banner of Truth.

Anderson, H 1976. The Gospel of Mark. London: Marshall, Morgan \& Scott.

Best, E 1978. Mark's use of the twelve, Zeitschrift für die neutestamentliche Wissenschaft und die Kunde der älteren Kirche, 69(1-2), 11-35.

Bill, T 2001. Reader's Digest Word Power Dictionary.

Bratcher, RG 1981. A translator's guide to the gospel of Mark. London: United Bible Society.

Bratcher, RG \& Nida, EA 1961. The Gospel of Mark, UBS Handbook series. New York.

Burn, JH 1974. The preacher's complete homiletic commentary on the Gospel according St Mark. Grand Rapids, Michigan: Baker Books.

Cahill, M 1996. Reader-response criticism and the allegorizing reader. Theological Studies, 57(1), 89-96.

Carson, DA, France RT, Motyer, JA, Wenham, GJ 1994. New Bible Commentary, $21^{\text {st }}$ century edition. Leicester, England: Intervarsity Press

Catchpole, DR 1997. 'Source, form and redactional criticism of the New Testament', in S.E. Porter, (ed.), Handbook to exegesis of the New Testament, 167-188, Brill, Leiden.

Derrett, JDM 2006. Armor-bearers of Christ (Mark 10:33-40), The Expository Times 117(11), 452-453.

DeSilva, DA 2000. Honor, patronage, kinship and purity: unlocking New Testament culture. Downers Grove: Intervarsity Press. 
Du Rand, JA 2005. 'Bringing the reader into exegetical play, applied to the gospel of John' in Du Rand (ed.), More than one way of reading the bible, Departement of biblical and religious studies, University of Johannesburg.

Earle, R, Blaney, STM \& Hanson, C 1955. Exploring the New Testament. Kansas City: Beacon Hill Press

Elliott, JH 1993. 'What is social-scientific criticism?' Guides to biblical scholarship, New Testament series. Minneapolis: Fortress,

Elmer, DH 2006. Cross-cultural Servant-hood. Downers Grove, Illinois: IVP books.

Finger, RH 1994. Open homes and fictive kin groups: Jesus reinvents the family, Daughters of Sarah 20(1), 18-22.

Henry, M 2010. The New Matthew Henry Commentary, ed. by MH Manser. Grand Rapids: Zondervan.

Horrel, DG 1999. 'Social-scientific interpretation of the New Testament: Retrospect and prospect', in DG Horrel (ed.), Social-scientific approaches to New Testament interpretation, 3-28, Edinburg: T \& T Clark.

Hutchison, D 2009. Servant-Hood: Jesus' Countercultural call to Christian Leaders, Bibliotheca Sacra 166(1), 53-69.

King James Version 1994. Holy Bible and Reference. Grand Rapids, Michigan: Zondervan.

Malina, BR 1986. Christian origins and cultural anthropology: practical models for biblical interpretation. Atlanta: John Knox Press.

Mounce RH \& Mounce WD (eds.) 2008. Greek and English interlinear New Testament (NASB/NIV). Grand Rapids: Zondervan.

Osiek, C \& Balch, DL 1997. Families in the New Testament world: households and house churches. Louisville: Westminster John Knox.

Porter, SE 1990. Why has not reader-response criticism caught on in New Testament studies?Lliterature and theology 4(3), 278-292. 
Powell, MA 2009. Introducing the New Testament: A historical literary, and theological Survey. Grand Rapids, Michigan: Baker Academic.

Resseguie, JL 1984. Reader-response criticism and the synoptic gospels, Journal of the American academy of religion 52(2), 307-324

Rhoads, DM 2004, Children of Abraham, children of God: metaphorical kinship in Paul's letter to the Galatians, Current in Theology 31(4), 282-297.

Robinson, DS 1940. Kinship and brotherhood, Shane quarterly 1(4), 329-335.

Sanner, AE 1979. The Gospel According to Mark, Beacon Hill, Kansas City.

Schroeder, EH 2006. A second look at the Gospel of Mark, Currents in Theology and Mission 33(4), 291-299.

Senior, D 1984. The passion of Jesus in the Gospel of Mark. Wilmington, Delaware: Michael Glazier.

Thurston, BB 2002. Preaching Mark. Minneapolis: Fortress Press.

Van Eck, E 2013a. When kingdoms are kingdoms no more: A socialscientific reading of the Mustard Seed (Lk 13:18-19), Acta Theologica 33(2): 226-254

Van Eck, E 2013b, Introduction to the New Testament: The Synoptic problem and introduction to and exegesis and theology of Mark. Pretoria: University of Pretoria, Faculty of Theology-Department of New Testament Studies.

Williamson, LR 1983. Interpretation: A Bible commentary for teaching and preaching. Atlanta: John Knox. 